\title{
Effects of mixture of branch order-based roots and nitrogen addition on root decay in a subtropical pine plantation
}

\author{
Liang Kou ${ }^{1,2}$ - Weiwei Chen ${ }^{1,2}$ - Wenlong Gao ${ }^{1,2}$ - Hao Yang $^{1} \cdot$ Huimin Wang ${ }^{1}$. \\ Shenggong $\operatorname{Li}^{1}$
}

Received: 15 April 2015 /Revised: 26 June 2015 / Accepted: 8 July 2015 /Published online: 24 July 2015

(C) Springer-Verlag Berlin Heidelberg 2015

\begin{abstract}
Non-additive effects may occur when branching order-based fine roots decompose in mixture, due to their distinct chemical composition. However, these effects and how they respond to increased nitrogen $(\mathrm{N})$ availability are poorly known. We conducted a 524-day field litterbag experiment to examine the potential non-additive effects of orderbased fine root decomposition and their responses to different rates of $\mathrm{N}$ addition in a Pinus elliottii (slash pine) plantation in China. The intact fine roots of slash pine trees were hierarchically dissected and split into two groups (lower-order roots (the first and second order roots) and higher-order roots (the third to fifth order roots)). The decomposition of these two root groups was monitored either separately or in 1:1 mixture. The non-additive effects did not occur when the two root groups decomposed in mixture. However, high rate of $\mathrm{N}$ addition shifted the root group interactions from additive to synergistic effects through contrasting effects on individual root group (lower-order roots). High rate of $\mathrm{N}$ addition retarded the decomposition of lower-order roots more in isolation than in mixture, due to the decreased binding of acid-unhydrolyzable residue to inorganic $\mathrm{N}$ ions in mixture. Therefore, we suggest that although stoichiometric heterogeneity holds within the branching hierarchy of fine roots, the tight coupling of $\mathrm{N}$ with acid-unhydrolyzable residue of root tissues may limit $\mathrm{N}$ use by microdecomposers, and thereby causing the additive effect. Since the mixing effect of order-based root decomposition is
\end{abstract}

Shenggong Li

lisg@igsnrr.ac.cn

1 Key Laboratory of Ecosystem Network Observation and Modeling, Institute of Geographic Sciences and Natural Resources Research, Chinese Academy of Sciences, Beijing 100101, China

2 University of Chinese Academy of Sciences, Beijing 100049, China affected by $\mathrm{N}$ addition, understanding the chemical heterogeneity within fine root systems and their linkage with ambient $\mathrm{N}$ availability during decomposition either in isolation or in mixture may facilitate the accurate prediction of root decomposition responses to $\mathrm{N}$ loading.

Keywords Decomposition $\cdot$ Root branching order $\cdot$ Mixing effect $\cdot$ Acid-unhydrolyzable residue $\cdot$ Nitrogen addition

\section{Introduction}

Decomposition of fine roots represents a significant $\mathrm{C}$ flux in terrestrial ecosystems (Silver and Miya 2001). Similar to leaves, fine roots in natural ecosystems generally decompose in mixtures comprising roots from different plant species (Robinson et al. 1999; De Graaff et al. 2011; Shi et al. 2013), and/or in mixtures comprising different diameters of roots from the same species (De Graaff et al. 2013). As a result of litter mixing, the decomposition of roots from a plant species may be affected by the decomposition of roots from other plant species, with additive or non-additive (e.g., synergistic and antagonistic) effects. The non-additive effects are commonly found in leaf mixtures (Harguindeguy et al. 2008; Wang et al. 2009; Cuchietti et al. 2014), with different chemical composition (Gartner and Cardon 2004). It has been demonstrated that the synergistic effect may occur through the complementary resource use by microdecomposers (Vos et al. 2013). The antagonistic effect, however, may occur as high amounts of secondary compounds such as phenolics from low-quality litter can decrease the decomposition of high-quality litters (Hättenschwiler et al. 2005). Despite this, only one study has focused on the potential non-additive effects on the decomposition of root mixtures of a perennial grass species (De Graaff et al. 2013). 
There exists a huge morphological and chemical heterogeneity within fine root systems of woody tree species (Pregitzer et al. 2002), and thus in root-derived decomposing materials (Hishi 2007; Xiong et al. 2013; Wang et al. 2014). The branching fine root systems could be hierarchically categorized into non-lignified lower-order roots (e.g., the distal first and second orders) and lignified higher-order roots (e.g., the proximal third to fifth orders) structurally supportive of lowerorder roots (Xia et al. 2010). Although the lower- and higherorder roots generally have contrasting life span (McCormack et al. 2013), they may decompose together when the longlived higher-order roots die in parallel with concurrent death of short-lived lower-order roots. Lower-order roots typically possess thinner diameter and higher nutrient concentrations (e.g., $\mathrm{N}$ and P) (Li et al. 2010), yet they decompose more slowly than higher-order roots (Fan and Guo 2010; Goebel et al. 2011), due to high amounts of acid-unhydrolyzable residue (which includes lignin and phenolics) (Xiong et al. 2013). Given the contrasting morphological and chemical traits among order-based roots, the traditional diameterbased (e.g., $<2 \mathrm{~mm}$ in diameter) root decomposition studies that mingle multiple orders of roots may bias the estimate of decomposition rate of fine roots due to occurrence of the nonadditive effects.

Human-induced anthropogenic $\mathrm{N}$ deposition has doubled the reactive N input into soils (Galloway et al. 2008), which may affect decomposition of mixed litters (Vivanco and Austin 2011). For instance, $\mathrm{N}$ addition could shift the interactions between component species in mixture from additive effect either to synergistic effect, as a result of positive response of individual component species within mixture (Vivanco and Austin 2011), or to antagonistic effect, due to the elimination of $\mathrm{N}$ limitation to the microbial decomposers in low-quality litters (Lin et al. 2013). Additionally, $\mathrm{N}$ addition could also shift the interactions from non-additive effects (antagonistic effect) to additive effect via reducing variations in litter quality and increasing detritivore abundance (Rosemond et al. 2010). However, these observations and corresponding mechanisms were built up primarily based on the empirical studies on leaf decomposition. As far as we know, information on the mixing effect of order-based fine root decomposition and its response to $\mathrm{N}$ loading is lacking.

Pinus elliottii (slash pine), native to North America, has been widely planted as one of important coniferous tree species for vegetation restoration in subtropical China, where $\mathrm{N}$ deposition rates are increasing (Liu et al. 2013). To test the mixing effect of order-based root decomposition and its responses to increased $\mathrm{N}$ availability, we conducted a field experiment of the decomposition of lower-order roots, higherorder roots, and a 1:1 mixture (mass basis) of the two root groups of $P$. elliottii at ambient and $\mathrm{N}$-fertilized conditions for 524 days. We used the decay rate, acid-unhydrolyzable residue concentration, and $\mathrm{N}$ release to characterize the decomposition patterns and responses to $\mathrm{N}$ addition of each root group. We hypothesized that (i) lower- and higher-order roots would decompose at a lower rate in isolation than in mixture (i.e., presence of the synergistic effect), due to the morphological and initial chemical differences between the two root groups; (ii) $\mathrm{N}$ addition would affect the interaction (mixing) effect between these two order-based root groups, since the complementary use of $\mathrm{N}$ by microbial decomposers during the decomposition would be reduced by the exogenous $\mathrm{N}$ addition; and (iii) the exogenous $\mathrm{N}$ effects on the decomposition of order-based root mixture would be N-rate-dependent, with the higher effects occurring under higher $\mathrm{N}$ rates.

\section{Materials and methods}

\section{Study site and experimental design}

This study was carried out at our ongoing $\mathrm{N}$-addition manipulative experiment site, which is situated at the Qianyanzhou (QYZ) Experimental Station of Red Soil and Hilly Land, Chinese Academy of Sciences (CAS), Jiangxi province, southeastern China $\left(26^{\circ} 44^{\prime} 29.1^{\prime \prime} \mathrm{N}, 115^{\circ} 03^{\prime} 29.2^{\prime \prime} \mathrm{E}\right.$, $102 \mathrm{~m}$ a.s.1.). The region is characterized by subtropical humid monsoon climate. The mean annual air temperature and mean annual precipitation are $17.9^{\circ} \mathrm{C}$ and $1475 \mathrm{~mm}$, respectively (Wen et al. 2010). Soils of the region are weathered from red sandstone and mudstone and classified as Typic Dystrudepts Udepts Inceptisols according to the USDA system (Wang et al. 2012). The organic matter content was $58.3 \pm$ $7.5 \mathrm{~g} \mathrm{~kg}^{-1}$ for $0-5 \mathrm{~cm}$ soil layer and $24.4 \pm 2.1 \mathrm{~g} \mathrm{~kg}^{-1}$ for 5-10 cm soil layer. The total $\mathrm{N}$ and $\mathrm{P}$ contents were, respectively, $1.7 \pm 0.3 \mathrm{~g} \mathrm{~kg}^{-1}$ and $217 \pm 60 \mathrm{mg} \mathrm{kg}^{-1}$ for $0-5 \mathrm{~cm}$ soil layer and $1.0 \pm 0.1 \mathrm{~g} \mathrm{~kg}^{-1}$ and $174 \pm 20 \mathrm{mg} \mathrm{kg}^{-1}$ for $5-10 \mathrm{~cm}$ soil layer. The original vegetation on the gently undulating terrain was evergreen broad-leaved forests, but it was heavily destroyed due to logging and land conversion for agricultural production prior to the 1980 s. The vegetation was restored around 1985 by planting slash pine (Pinus elliottii), Masson pine (Pinus massoniana), and Chinese fir (Cunninghamia lanceolata). The understory vegetation is dominated by Woodwardia japonica, Loropetalum chinense, and Dicranopteris dichotoma (Wang et al. 2012). The ambient wet $\mathrm{N}$ deposition rate at the site is about $10 \mathrm{~kg} \mathrm{~N} \mathrm{ha}^{-1}$ year $^{-1}$ with approximately $68 \%$ being ammonium-N (Zhan et al. 2014). More detailed site information is available in Kou et al. (2015a).

In November 2011, we laid out nine plots $(20 \times 20 \mathrm{~m}$, slope angle $<15^{\circ}$ ) in a randomized complete block design. The neighboring plots were isolated by a buffer zone (at least $10 \mathrm{~m}$ ) and subjected to three $\mathrm{N}$ addition rates: control (ambient $\mathrm{N}$ deposition), +40 (low $\mathrm{N}$ ), and +120 (high $\mathrm{N}$ ) kg N ha $^{-1}$ year ${ }^{-1}\left(\mathrm{NH}_{4} \mathrm{Cl}\right)$ above the ambient atmospheric $\mathrm{N}$ 
deposition rate. Each treatment was replicated three times. Fertilizers were weighed and fully dissolved in $30 \mathrm{~L}$ tap water, and then evenly sprayed onto $\mathrm{N}$-addition zone on non-rainy days. The control plots were supplied with equivalent amount of tap water. The N addition initiated on 1 May 2012 and proceeded at a month interval to simulate chronic atmospheric $\mathrm{N}$ deposition that would occur over time.

\section{Root-derived material preparation}

Intact fine roots were dug out from the $0-10 \mathrm{~cm}$ mineral soil layer under a non-disturbed $P$. elliottii plantation forest and brought to laboratory within $2 \mathrm{~h}$ in mid-May 2013. Soil and organic matter particles adhering to roots were gently rinsed off with running water. Root orders of the clean live roots were identified using fine forceps following the protocol of Pregitzer et al. (2002). In this study, only the first five order roots were reserved and partitioned into two groups (decomposing substrates), based on the similarity in tissue chemistry (Xia et al. 2010). Most distal two order roots (the first and second orders) were combined as lower-order roots and the proximal three order roots (the third to fifth orders) were grouped into higher-order roots. Diameter, specific root length, and root tissue density of these two root groups were determined in September 2013 (Kou et al. 2015a). The classified roots were first air-dried and stored for about 1 week, and then oven-dried to a constant mass at $40{ }^{\circ} \mathrm{C}$.

\section{Litterbag arrangement, harvest, and root litter chemical analyses}

Nylon litterbags $(10 \times 10 \mathrm{~cm}, 0.1 \mathrm{~mm}$ meshed) were filled with $2.003 \pm 0.002 \mathrm{~g}$ (dry weight) branching order-based roots as decomposing substrates. The litterbags consisted of either lower-order roots or higher-order roots or a mixture in equal proportions of the two order-based root groups $(1.001 \pm 0.001$ for lower-order roots and $1.003 \pm 0.002$ for higher-order roots). Although the small mesh size would unavoidably limit the entrance of some decomposer organisms (e.g., microarthropods) into litterbags, yet it prevented the physical loss of lower-order roots. On 23 May 2013, one subplot (2.5× $3.0 \mathrm{~m}$ ) was established at the center of each plot. All the litterbags were buried at an angle of approximately $30^{\circ}$ to the vertical direction and fixed on the ground using nylon strings and steel nails. An additional set of three replicates of each root group was used for initial chemical analyses.

The litterbags were collected after 69 (31 July 2013), 190 (29 November 2013), 281 (28 February 2014), 371 (29 May 2014), and 524 (29 October 2014) days of decomposition. On each harvest date, one litterbag of each type of decomposing substrates was collected from each subplot. Any litterbags broken by soil animals or contaminated by pine oil or root exudates, another one would be sampled for residual mass determination and chemical analysis. The laboratory processing of the harvested litterbags was situation-dependent. When the litterbags were dry, they were immediately cleaned by gently brushing away the soil outside. However, when the litterbags were wet, they were first oven-dried, and then their clay particles attached were carefully removed prior to opening the litterbags. Additionally, the in-growing roots and sometimes tiny arthropods were also removed from the litterbags by tweezers. The retrieved root litter was oven-dried to a constant weight at $40{ }^{\circ} \mathrm{C}$ to determine the residual mass. To identify the $\mathrm{N}$ addition effects on the decomposition of individual root group, lower- and higher-order roots in mixture were separated based on root color (dark-brown for lower-order roots vs. yellowish-brown for higher-order roots), size (ca. $3 \mathrm{~mm}$ for lower-order roots vs. $>25 \mathrm{~mm}$ for higher-order roots in length (data not shown); $0.33 \mathrm{~mm}$ for lower-order roots vs. $0.77 \mathrm{~mm}$ for higher-order roots in diameter), and texture (smooth for lower-order roots vs. rough for higher-order roots). More specifically, the larger-size higher-order roots were first picked out, and then dark-brown lower-order roots were separated from the remaining smaller-size, rough higher-order roots using forceps. In this study, the separation of root mixtures could only be achieved at the first four harvest dates due to the severe fragmentation of higher-order roots at the final harvest date (524 days).

Both the chemical composition and $\mathrm{C}$ fraction (extractives, acid-unhydrolyzable residue, and acid-hydrolyzable residue) of lower- and higher-order roots were determined. All root samples were ground with a Restch MM400 mixer mill (Retsch GmbH, Haan, Germany) to determine the content of $\mathrm{C}$ and $\mathrm{N}$ using a Vario MACRO cube elemental analyzer (Elementar, Germany). Carbon fraction was determined by the sulfuric acid digestion method combined with chloroform-methanol extraction (Ryan et al. 1990; Xiong et al. 2013; Kou et al. 2015b). Specifically, a milled powder subsample (200-300 mg) was first extracted with chloroform-methanol $(2: 1 v / v, 15 \mathrm{ml})$ for $2 \mathrm{~h}$ and then filtered. The oven-dried residue was digested with sulfuric acid (72\%, $15 \mathrm{ml})$ for $3 \mathrm{~h}$ and then centrifuged $(2470 \times \mathrm{g}, 8 \mathrm{~min})$. Supernatants in centrifuge tubes $(50 \mathrm{ml})$ were repeatedly replaced with deionized water (approximately ten times) until the $\mathrm{pH}$ was 7 . The residue was filtered through a cellulose acetate membrane $(0.45 \mu \mathrm{m})$ with a vacuum pump and oven-dried to a constant weight $(W)$. Ash content of sample and of the residue $(W)$ was determined by combusting samples $(40-50 \mathrm{mg})$ in muffle furnace at $550{ }^{\circ} \mathrm{C}$ for $4 \mathrm{~h}$. The acid-unhydrolyzable residue concentration was calculated as follows: acid-unhydrolyzable residue concentration $(\%)=(W-$ ash-in- $W) \times 100 /$ (subsample - ashin-subsample). All initial root chemical parameters and residual mass over time were expressed on an ash-free, dry mass basis.

\section{Statistical analysis}

Root decomposition rate was fitted to a first-order negative exponential decay equation (Olson 1963): $X_{t}=X_{0} e^{-k t}$, where 
$X_{t}$ is the residual mass at time $t, X_{0}$ is the initial mass, $e$ is the base of natural logarithm, and $k$ is the decay rate constant. The mixing effect of order-based roots was assessed by comparing the observed against expected values (residual mass and $k$ ) using Student's $t$ test. In this study, the "observed" represents the residual mass or $k$ of lower- and higher-order roots when they decomposed in mixture, and the "expected" refers to the average of lower- and higher-order roots when they decomposed in isolation. The mixing effect is synergistic when the observed is higher than the expected, and on the opposite, the mixing effect is antagonistic.

One-way ANOVA was used to test the interspecific differences of morphological traits and initial tissue chemistry parameters among root-derived decomposing substrates. Repeated measures two-way ANOVA were used to test the effects of $\mathrm{N}$ treatments $(\mathrm{CK}$, low $\mathrm{N}$, and high $\mathrm{N}$ ) and decomposition conditions ("isolation" vs. "mixture" for each root group or "observed" vs. "expected" for the whole mixture) on residual mass (\% of initial mass), residual acidunhydrolyzable residue (\% of initial mass), and residual $\mathrm{N}$ (\% of initial mass) of roots. Except on the final harvest date (524 days), when higher-order roots in the litterbags were severely fragmented, on other harvest dates $(69,190,281$, and 371 days), parameters above for each root group in mixture were measured separately to assess the separate effect of the mixing decomposition on each root group. For these parameters of each root group, the significant differences between "isolation" and "mixture" at different $\mathrm{N}$-addition treatment conditions were further examined by Student's $t$ test. Data were log-transformed where necessary to improve normality and reduce heteroscedasticity. Significant differences between means were compared using Tukey's HSD test. Linear regression analysis was carried out to determine the relationships between expected residual mass and observed residual mass with respect to different $\mathrm{N}$ addition rates. All statistical analyses were performed using the SPSS software version 18.0.

\section{Results}

\section{Root morphological traits and initial tissue chemistry}

Lower-order roots had smaller mean diameter, higher specific root length (SRL), but lower root tissue density (RTD) than higher-order roots. In addition, lower-order roots had higher extractives and acid-unhydrolyzable residue and $\mathrm{N}$ concentrations, but lower acid-hydrolyzable residue concentration relative to higher-order roots. In terms of their ratios, lower-order roots had lower $\mathrm{C} / \mathrm{N}$, acid-unhydrolyzable residue/ $\mathrm{N}$, and acid-hydrolyzable residue/ $\mathrm{N}$ ratios, but higher acidunhydrolyzable residue/acid-hydrolyzable residue ratios compared with higher-order roots (Table 1). Above parameters 
lied in the intermediate values for the mixture of lower- and higher-order roots, except for the extractives (Table 1).

\section{Mixing effect of order-based root decay and its responses to $\mathbf{N}$ addition}

Decay rate constants $(k)$ did not differ significantly between the "observed" (the 1:1 mixture) and "expected" (the average of lower- and higher-order roots decomposing separately) at ambient conditions $(P>0.05$, Fig. 1), indicating that the additive effects occurred in the decomposition of order-based root

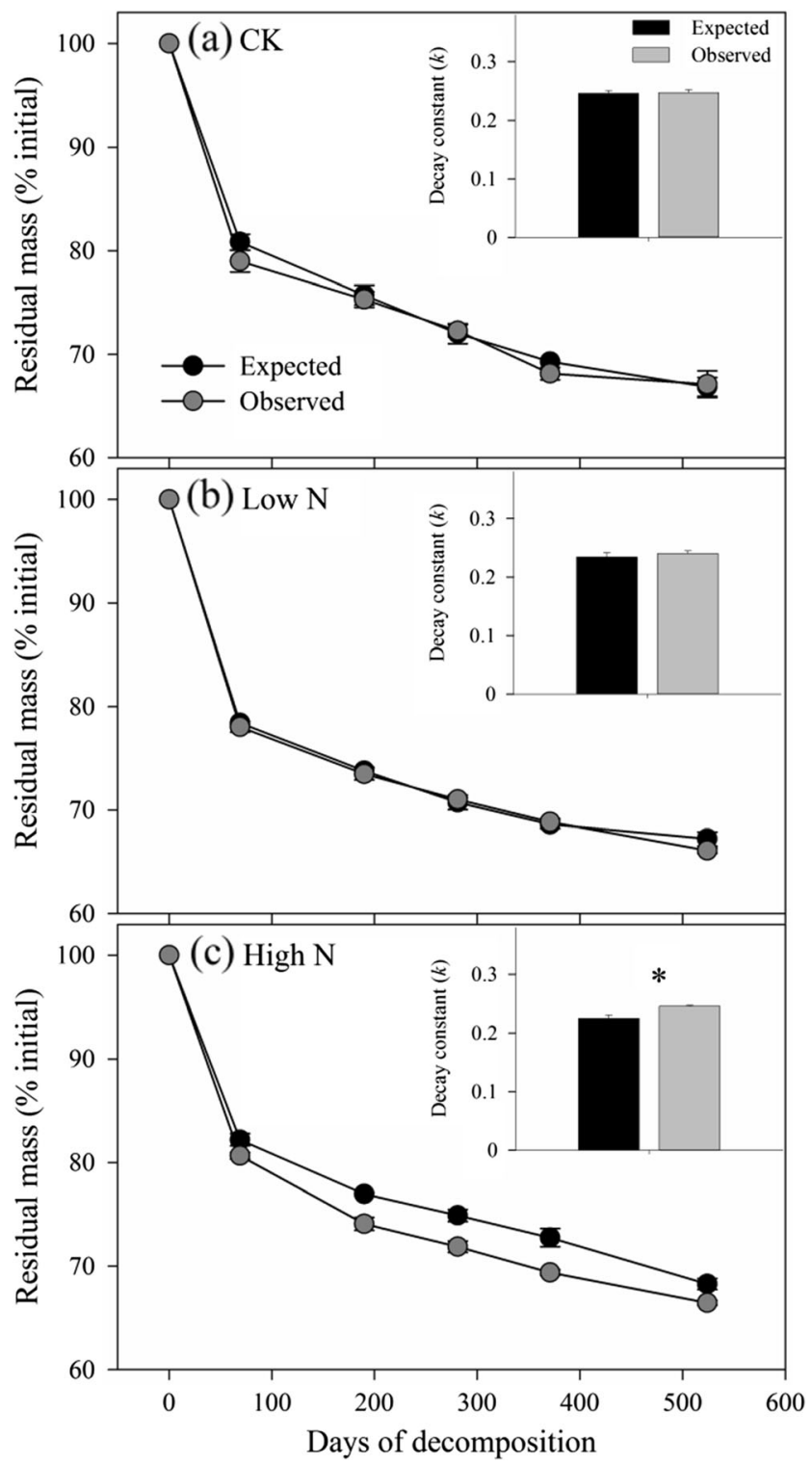

Fig. 1 Decomposition (residual mass over time and decay constant $k$ ) of order-based root mixtures of $P$. elliottii under ambient (a), low (b), and high (c) $\mathrm{N}$ addition rates. Data are expressed as means \pm standard error $(n=3, P<0.05)$. The observed decomposition (lower- and higher-order roots when decomposed in mixture) is indicated by gray-filled circles, and the expected decomposition (lower- and higher-order roots when decomposed in isolation) is indicated by black-filled circles mixture. Different rates of $\mathrm{N}$ addition exerted differential effects on the mixture decomposition of lower- and higher-order roots $(P=0.002$, Table $2 ;$ Fig. 1$)$. The high $\mathrm{N}$ rate significantly stimulated the decomposition of order-based root mixture (Fig. 1c), indicating a shift from the additive effect to the synergistic effect. However, the low $\mathrm{N}$ rate did not eliminate the additive effect of root mixture (Fig. 1b). The observed residual mass significantly correlated with the expected residual mass under both ambient and $\mathrm{N}$ addition conditions $\left(R^{2}\right.$ ranges from 0.935 to $0.949, P<0.0001$, Fig. 2).

\section{Decay of individual root group and its responses to $\mathrm{N}$ addition}

During the first 371 days, decomposition of lower-order roots did not differ significantly when in isolation or in mixture both at ambient (Fig. 3a) and low $\mathrm{N}$ rate (Fig. 3b), but lower-order roots decomposed faster in mixture than in isolation at high $\mathrm{N}$ rate $(P<0.001$, Fig. 3 c). Regardless of $\mathrm{N}$ addition, no significant difference was observed for higher-order roots when decomposed separately or in mixture (Fig. 3d-f).

\section{Acid-unhydrolyzable residue concentrations and $\mathrm{N}$ release patterns of root groups}

At high $\mathrm{N}$ rate, the residual acid-unhydrolyzable residue $(\%$ of initial mass) was significantly higher in lower-order roots decomposing separately than in mixture $(P<0.001$, Fig. $4 c)$, but there were no differences at ambient (Fig. 4a) and low N rate (Fig. 4b). For higher-order roots, the residual acidunhydrolyzable residue did not differ significantly when decomposed separately or in mixture at all $\mathrm{N}$ rates (Fig. $4 \mathrm{~d}-$ f). Lower-order roots generally experienced net $\mathrm{N}$ release when decomposed separately or in mixture at ambient (Fig. 5a) and low $\mathrm{N}$ rate (Fig. 5b), but showed $\mathrm{N}$ immobilization when decomposed separately at high $\mathrm{N}$ rate $(P=0.019$, Fig. 5c). Higher-order root decomposition experienced $\mathrm{N}$ immobilization at all $\mathrm{N}$ rates (Fig. $5 \mathrm{~d}-\mathrm{f}$ ). Higher-order roots showed higher $\mathrm{N}$ immobilization when decomposed separately than in mixture at both low- $(P=0.002$, Fig. 5 e) and high-N $(P=0.010$, Fig. 5f) rates.

\section{Discussion}

\section{Additive effect of order-based root decay}

In contrast to our first hypothesis, decomposition of lowerand higher-order root mixture did not present synergistic effects (Fig. 1a). Previous studies have shown that non-additive effects can occur as roots of multiple plant species were mixed, which may be due to their different chemical composition (Robinson et al. 1999; De Graaff et al. 2011). We 
Table 2 Results of the repeated measures two-way ANOVA for residual mass, residual acid-unhydrolyzable residue, and residual $\mathrm{N}$, with different $\mathrm{N}$ addition rates $(\mathrm{CK}$, low $\mathrm{N}$, and high $\mathrm{N})$ and

\begin{tabular}{|c|c|c|c|c|c|c|c|c|}
\hline \multirow[t]{2}{*}{ Root type } & \multirow[t]{2}{*}{ Source of variation } & & \multicolumn{2}{|c|}{ Residual mass } & \multicolumn{2}{|c|}{ Residual AUR } & \multicolumn{2}{|c|}{ Residual N } \\
\hline & & & $\mathrm{F}$ & $P$ & $\mathrm{~F}$ & $P$ & $\mathrm{~F}$ & $P$ \\
\hline \multirow[t]{7}{*}{ Lower-order roots } & \multirow[t]{3}{*}{ Between subjects } & Treatment & 17.306 & $<0.001$ & 16.462 & $<0.001$ & 11.207 & 0.002 \\
\hline & & Condition & 16.901 & 0.001 & 21.978 & 0.001 & 5.038 & 0.044 \\
\hline & & Treatment $\times$ condition & 5.566 & 0.019 & 3.215 & 0.076 & 0.195 & 0.825 \\
\hline & \multirow[t]{4}{*}{ Within subjects } & Time & 168.564 & $<0.001$ & 4.951 & 0.006 & 16.576 & $<0.001$ \\
\hline & & Time $\times$ treatment & 1.650 & 0.181 & 1.111 & 0.375 & 0.593 & 0.733 \\
\hline & & Time $\times$ condition & 0.546 & 0.662 & 1.908 & 0.146 & 4.248 & 0.011 \\
\hline & & Time $\times$ treatment $\times$ condition & 0.301 & 0.930 & 0.310 & 0.928 & 0.635 & 0.702 \\
\hline \multirow[t]{7}{*}{ Higher-order roots } & \multirow[t]{3}{*}{ Between subjects } & Treatment & 14.118 & 0.001 & 8.925 & 0.004 & 5.148 & 0.024 \\
\hline & & Condition & 0.027 & 0.873 & 1.068 & 0.322 & 10.372 & 0.007 \\
\hline & & Treatment $\times$ condition & 0.968 & 0.408 & 0.780 & 0.480 & 0.330 & 0.725 \\
\hline & \multirow[t]{4}{*}{ Within subjects } & Time & 515.485 & $<0.001$ & 115.663 & $<0.001$ & 0.689 & 0.565 \\
\hline & & Time $\times$ treatment & 3.710 & 0.006 & 0.939 & 0.479 & 0.345 & 0.908 \\
\hline & & Time $\times$ condition & 4.458 & 0.009 & 1.854 & 0.155 & 0.176 & 0.912 \\
\hline & & Time $\times$ treatment $\times$ condition & 1.820 & 0.123 & 0.364 & 0.897 & 0.571 & 0.751 \\
\hline \multirow[t]{7}{*}{ The whole } & \multirow[t]{3}{*}{ Between subjects } & Treatment & 11.082 & 0.002 & 13.492 & 0.001 & 7.157 & 0.009 \\
\hline & & Condition & 9.327 & 0.010 & 0.026 & 0.874 & 9.283 & 0.010 \\
\hline & & Treatment $\times$ condition & 3.707 & 0.056 & 0.126 & 0.883 & 0.242 & 0.789 \\
\hline & \multirow[t]{4}{*}{ Within subjects } & Time & 600.167 & $<0.001$ & 87.289 & $<0.001$ & 3.342 & 0.030 \\
\hline & & Time $\times$ treatment & 3.252 & 0.005 & 0.396 & 0.917 & 0.538 & 0.776 \\
\hline & & Time $\times$ condition & 0.392 & 0.813 & 22.680 & $<0.001$ & 0.431 & 0.732 \\
\hline & & Time $\times$ treatment $\times$ condition & 1.635 & 0.140 & 0.265 & 0.974 & 0.562 & 0.758 \\
\hline
\end{tabular}

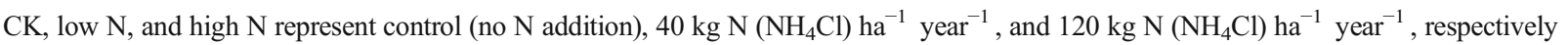

therefore expected that mixing order-based root groups from a single species would also present non-additive effects if they have contrasting tissue chemistry. However, the "observed"

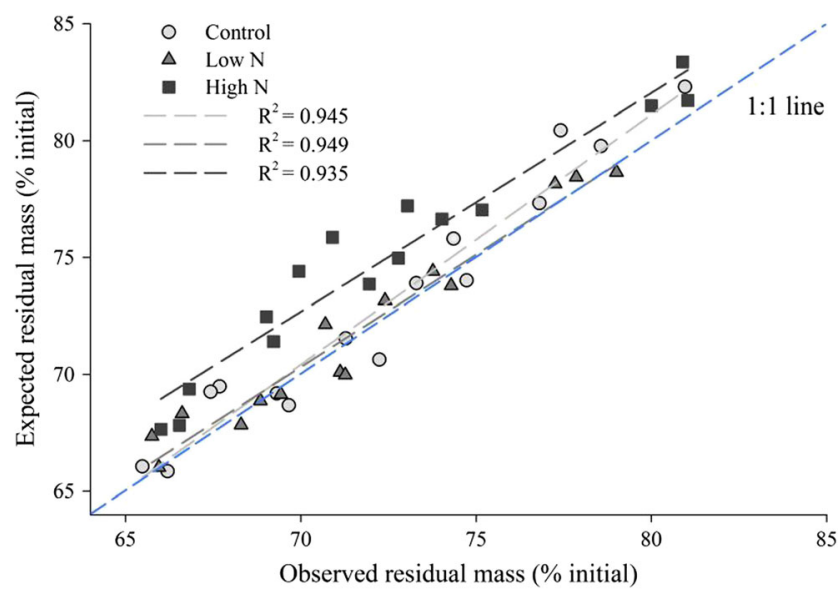

Fig. 2 Relationships between observed residual mass ( $\%$ of initial mass, $n=15)$ and expected residual mass ( $\%$ of initial mass, $n=15)$ under ambient and $\mathrm{N}$ addition conditions: light-gray circles indicate control; medium-gray triangles, low $\mathrm{N}$ rate; dark-gray squares, high $\mathrm{N}$ rate. Blue dashed line represents 1:1 line decomposition conditions ("isolation" vs. "mixture" for each root group, or "observed" vs. "expected" for the whole mixture) as factors 

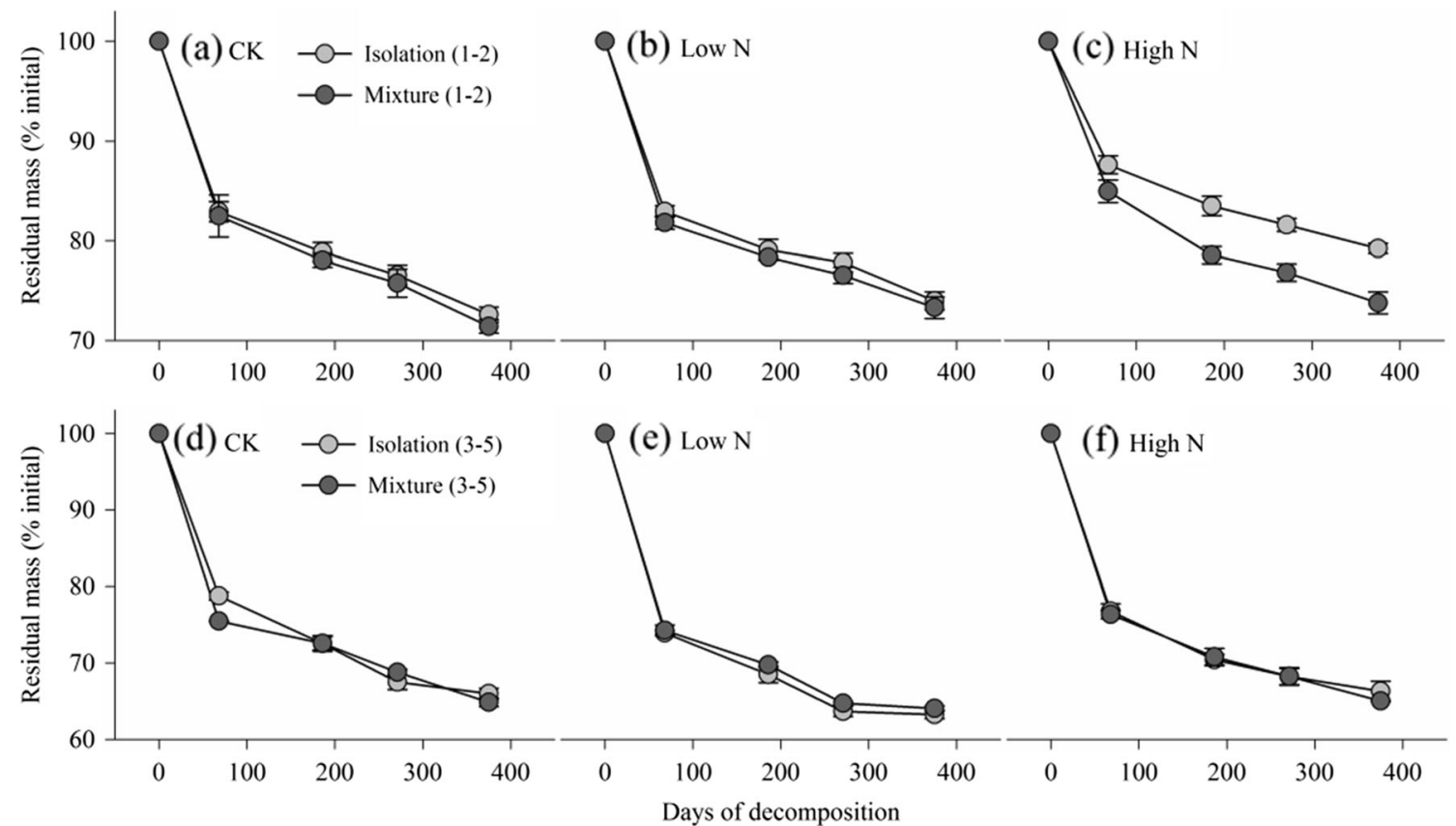

Fig. 3 Residual mass (\% of initial mass) of order-based fine root decomposition in isolation or in mixture under ambient $(\mathbf{a}, \mathbf{d})$, low (b, e), and high $(\mathbf{c}, \mathbf{f}) \mathrm{N}$ addition rates during the first 371-day decomposition. a-c Lower-order roots; d-f higher-order roots. Gray- filled circles indicate decomposition of root groups in isolation, and black-filled circles indicate decomposition of root groups in mixture. Data are expressed as means \pm standard error $(n=3, P<0.05)$

groups actually occurred as they decomposed in mixture (Fig. 3a, d), indicating that stoichiometric dissimilarity may not always drive the synergistic effect (Hättenschwiler and et al. 2008), and thus they have higher $\mathrm{N}$ and $\mathrm{P}$ concentrations than higher-order roots (Pregitzer et al. 2002; Li et al. 2010). However, no interaction between the two order-based root
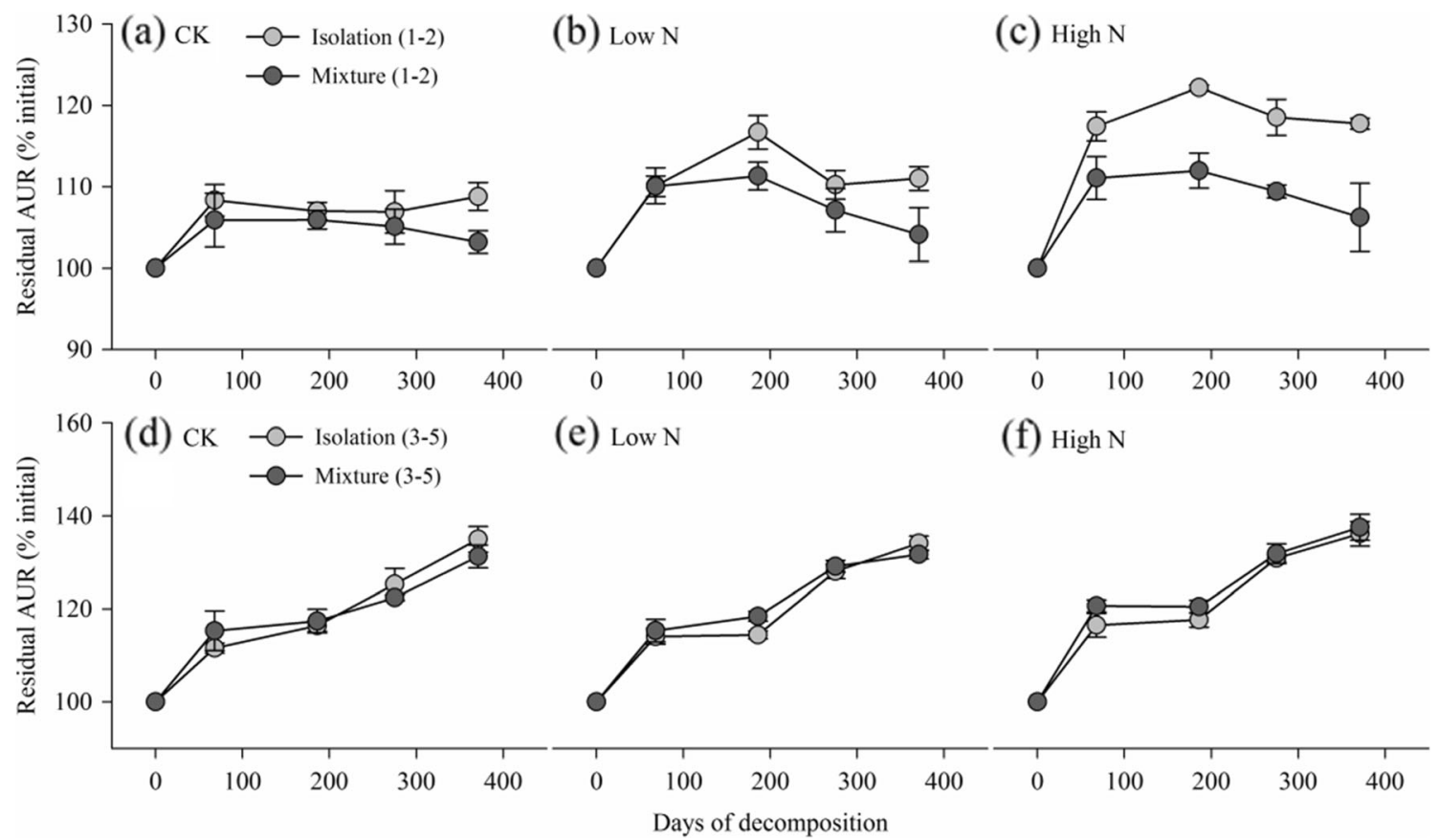

Fig. 4 Residual acid-unhydrolyzable residue (\% of initial mass) of orderbased fine root decomposition in isolation or in mixture under ambient $(\mathbf{a}, \mathbf{d})$, low $(\mathbf{b}, \mathbf{e})$, and high $(\mathbf{c}, \mathbf{f}) \mathrm{N}$ addition rates during the first 371-day decomposition. a-c Lower-order roots; d-f higher-order roots. Gray- filled circles indicate decomposition of root groups in isolation, and black-filled circles indicate decomposition of root groups in mixture. Data are expressed as means \pm standard error $(n=3, P<0.05)$ 

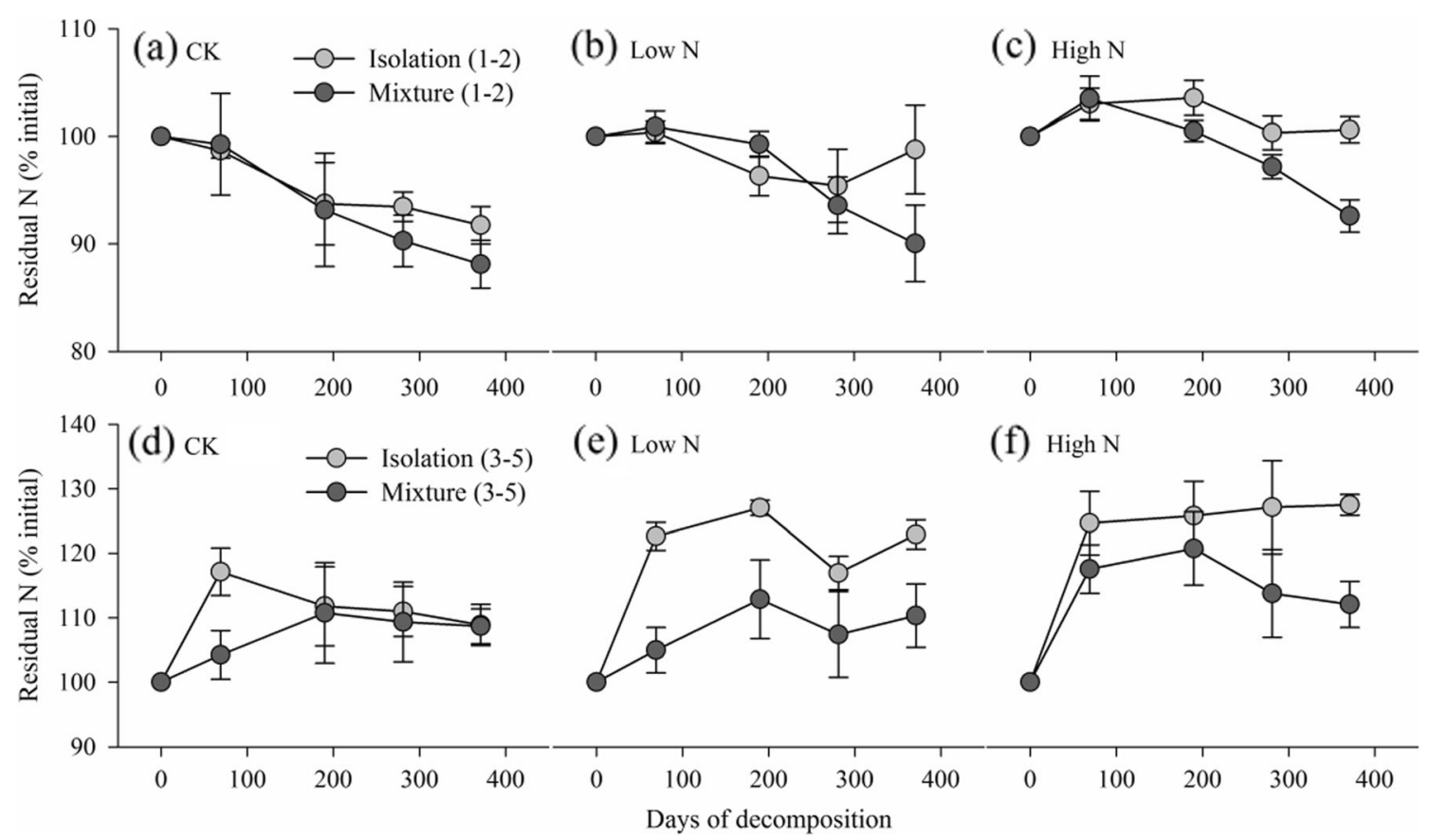

Fig. 5 Residual N (\% of initial mass) of order-based fine root decomposition in isolation or in mixture under ambient $(\mathbf{a}, \mathbf{d})$, low $(\mathbf{b}, \mathbf{e})$, and high $(\mathbf{c}, \mathbf{f}) \mathrm{N}$ addition rates during the first 371-day decomposition. a-c Lower-order roots; $\mathbf{d}-\mathbf{f}$ higher-order roots. Gray- filled circles indicate decomposition of root groups in isolation, and black-filled circles indicate decomposition of root groups in mixture. Data are expressed as means \pm standard error $(n=3, P<0.05)$
Jørgensen 2010). Although lower-order roots possessed higher $\mathrm{N}$ concentration, they had similar acid-unhydrolyzable residue/ $\mathrm{N}$ ratios to higher-order roots (Table 1). This implies that the tissue $\mathrm{N}$ concentration increases in proportion to acidunhydrolyzable residue of order-based roots and much of the $\mathrm{N}$ in lower-order roots is tightly bound in acid-unhydrolyzable residue (Xiong et al. 2013). Hence, the complementary resource (e.g., N) use by microbial decomposers (Vos et al. 2013) or priming effects of high-quality litters on low-quality litters (Wardle et al. 1997) may, to some extent, be hindered due to the limited $\mathrm{N}$ release. Alternatively, the high amount of polyphenols (e.g., chitin and tannin, collectively referred to as acid-unhydrolyzable residue) in lower-order roots typically exerts negative effects on decomposition (Langley et al. 2006) and thus may offset the positive effects of $\mathrm{N}$ transfer (if any) on decomposition of root mixture.

\section{Responses of mixing effect of order-based root decomposition to $\mathbf{N}$ addition}

Exogenous $\mathrm{N}$ addition shifted the additive effect of orderbased root mixture decomposition to synergistic effect $(P=$ 0.002 , Table 2 ; Fig. $1 \mathrm{c}$ ), which partly supports our second hypothesis that $\mathrm{N}$ addition could affect the interaction among order-based root mixture decomposition. This finding confirms a previous study that $\mathrm{N}$ addition transformed neutral effects of leaf mixtures to positive non-additive effects on mass loss during decomposition (Vivanco and Austin 2011). The phenomenon has been only observed in few studies on mixture decomposition of leaf litter (Rosemond et al. 2010; Vivanco and Austin 2011; Lin et al. 2013) and depends on different mechanisms. Nitrogen addition can shift the interactions of decomposing component species from antagonistic effect to additive effect, via reducing competition among different microbial decomposers (Rosemond et al. 2010). In addition, $\mathrm{N}$ addition could also transform the decomposing species interactions from additive effect to antagonistic effect, due to ameliorated $\mathrm{N}$ limitation to the microbial decomposers acting on low-quality component species (Lin et al. 2013).

The modification of $\mathrm{N}$ addition on litter species interactions during decomposition may be induced by individual species responses (Vivanco and Austin 2011). We separated lowerorder roots from higher-order roots in mixture (except the final harvest date) and found that $\mathrm{N}$ addition exerted neutral effects on higher-order roots irrespective of decomposition conditions ("isolation" or "mixture") (Fig. 3e, f), but stronger retarding effects on lower-order root decomposition when they decomposed in isolation than in mixture $(P<0.001$, Fig. 3c). This indicates that the shift of the mixing effect was mainly driven by responses of lower-order roots. It has been reported that the acid-unhydrolyzable residue (i.e., lignin and phenolics) in decomposing litters can bind to inorganic $\mathrm{N}$ ions to form recalcitrant compounds (new acid-unhydrolyzable residue), and thus decreases decomposition rate (Fog 1988; 
Berg and Matzner 1997). We observed that $\mathrm{N}$ addition increased the residual acid-unhydrolyzable residue (\% of initial dry mass) of lower-order roots when they decomposed separately, but not when they decomposed in mixture (Fig. 4c), which could be interpreted as evidence for the differential $\mathrm{N}$ effects on lower-order roots under different decomposition conditions $(P=0.019$, Table 2$)$. With respect to the weak $\mathrm{N}$ effects on lower-order roots in mixture, we speculate that higher-order roots in mixture may reduce the affinity between inorganic $\mathrm{N}$ ions and acid-unhydrolyzable residue via physically (larger diameter of higher-order roots) impeding the access of inorganic $\mathrm{N}$ ions to lower-order roots and/or chemically (higher $\mathrm{C} / \mathrm{N}$ ratio of higher-order roots) increasing the use of inorganic $\mathrm{N}$ ions by microorganisms acting on higher-order roots.

\section{N-rate effect on interactions of order-based root decay}

As predicted, high rate $\left(120 \mathrm{~kg} \mathrm{~N} \mathrm{ha}^{-1}\right.$ year $\left.^{-1}\right)$ rather than low rate $\left(40 \mathrm{~kg} \mathrm{~N} \mathrm{ha}^{-1}\right.$ year $\left.{ }^{-1}\right)$ of $\mathrm{NH}_{4} \mathrm{Cl}$ addition affected the interactions among order-based root mixture decomposition (Fig. 1b, c). Given the individual responses of root groups in mixture to $\mathrm{N}$ addition (Fig. 3c), lower-order roots could be used as a proxy to interpret the differential responses of root mixture to different $\mathrm{N}$ rates. It has been shown that the binding of acid-unhydrolyzable residue to $\mathrm{N}$ ions under field conditions can be stimulated by increasing ${ }^{15} \mathrm{~N}$-labeled ammonium rates (Axelsson and Berg 1988). In a previous study, we observed that relative to low $\mathrm{N}$ rate, high $\mathrm{N}$ rate exerted stronger retarding effects on decomposition of lower-order roots in isolation via promoting the binding of acid-unhydrolyzable residue to inorganic $\mathrm{N}$ ions (Kou et al. 2015b). However, the residual acid-unhydrolyzable residue of lower-order roots in mixture did not increase by increasing the $\mathrm{N}$ rate, suggesting no promoted binding of acid-unhydrolyzable residue to inorganic $\mathrm{N}$ ions by $\mathrm{N}$ addition. Additionally, we found significant interactive effects of "N treatment" by "decomposition condition" on residual mass of lower-order roots $(P=0.019$, Table 2), which in parallel contributes to explaining the N-rate effect on mixture decomposition. Due to the smaller size of lower-order roots, we speculate that the weakened binding effects could be ascribed to the low amount of lower-order roots in mixture (half of that in isolation decomposition), which may reduce the potential of lower-order roots to bind the free $\mathrm{N}$ ions.

The N-rate effect could alternatively be explained by the neighbor effects of higher-order roots on lower-order roots. Due to the relatively lower quality (Pregitzer et al. 2002; Fan and Guo 2010), higher-order roots in mixture may serve as a competitor via inorganic $\mathrm{N}$ immobilization, thus decreasing the $\mathrm{N}$ interactions with the acid-unhydrolyzable residue of lower-order roots. It has been demonstrated that relative to low rate of $\mathrm{N}$ addition $\left(54 \mathrm{~kg} \mathrm{~N} \mathrm{ha}^{-1}\right.$ year $\left.^{-1}\right)$, high rate of $\mathrm{N}$ addition (170 $\mathrm{kg} \mathrm{N} \mathrm{ha}^{-1}$ year $\left.^{-1}\right)$ can increase the $\mathrm{N}$ immobilization in both above- and below-ground litters (Norris et al. 2013). We found that the $\mathrm{N}$ addition at the high rate, to some extent, increased the $\mathrm{N}$ immobilization in higher-order roots as compared to the low rate (Fig. 5f), which may suggest high demand of microbial $\mathrm{N}$ during decomposition of higher-order roots. Hence, the presence of N-rate effect is probably due to the fact that the decomposition of lower-order roots in isolation would be retarded by the increase of $\mathrm{N}$ rate, but the retarding effect is buffered during the decomposition of mixture by the presence of higher-order roots.

The current decomposition experiment has several limitations, which need to be noticed. Specifically, like other root decomposition studies (Xiong et al. 2013; Zhao et al. 2014), litterbags with small-sized mesh $(0.1 \mathrm{~mm})$ were employed in this study. Although this mesh size may successfully avoid the physical loss of lower-order roots, it actually impedes the access of soil fauna into litterbags. Soil fauna plays an important role in litter decomposition and determines the magnitude and direction of litter diversity effects (Hättenschwiler and Gasser 2005). Hence, the lack of involvement of soil fauna may, to some extent, affect the pattern of the mixing effect. Secondly, we applied $\mathrm{NH}_{4} \mathrm{Cl}$ as fertilizers to simulate the dominant $\mathrm{NH}_{4}{ }^{+}$deposition in this region (Zhan et al. 2014). Despite that the effects of $\mathrm{NH}_{4}{ }^{+}$on decomposition were captured, we could not rule out the possibility that external chloride ions also might contribute to the decomposition process. Considering the toxicity of chloride ions to microorganisms (Zahran 1997; Megda et al. 2014), it may affect decomposition via inhibiting the growth and activities of microorganisms. Hence, future studies should take into account the potential effects of salinity stress (e.g., $\mathrm{Cl}^{-}$) on decomposition. Finally, this study used only one pine tree species and one mixing ratio (1:1). Given the complexity of the natural decomposition conditions, further studies are required to investigate mixture decomposition of order-based roots with different mixing ratios and among multiple species, and mechanistically reveal their responses to $\mathrm{N}$ loading.

\section{Conclusions}

To the best of our knowledge, this is the first report on orderbased root mixture decomposition and its response to increased $\mathrm{N}$ availability. We found that (1) additive effects occurred during order-based root mixture decomposition of P. elliottii; (2) like leaf mixture decomposition, $\mathrm{N}$ addition affected the decomposition of root groups (lower-order roots) in order-based root mixture; and (3) the effect depended on the $\mathrm{N}$ addition rate. Our results indicate that the tight bound of $\mathrm{N}$ in acid-unhydrolyzable residue may hinder the priming effects or the complementary use of $\mathrm{N}$ by microbial decomposers, and thus result in the additive effect. The mixing effect 
and its dependence upon $\mathrm{N}$ availability during decomposition of order-based roots with different chemical composition have implications for the accurate prediction of root decomposition and its responses to increased $\mathrm{N}$ loading.

Acknowledgments This research is financially supported by the grants from the National Natural Science Foundation of China (No. 31130009) and the National Key Project of Scientific and Technical Supporting Program (No. 2013BAC03B03). The authors acknowledge the contributions of the editor and anonymous reviewers in improving this manuscript.

Conflict of interest The authors declare no competing financial interests.

\section{References}

Axelsson G, Berg B (1988) Fixation of ammonia $\left({ }^{15} \mathrm{~N}\right)$ to Pinus silvestris needle litter in different stages of decomposition. Scand J For Res 3: 273-279. doi:10.1080/02827588809382515

Berg B, Matzner E (1997) Effect of N deposition on decomposition of plant litter and soil organic matter in forest systems. Environ Rev 5: $1-25$

Chapman SK, Koch GW (2007) What type of diversity yields synergy during mixed litter decomposition in a natural forest ecosystem? Plant Soil 299:153-162. doi:10.1007/s11104-007-9372-8

Cong WF, van Ruijven J, van der Werf W, De Deyn GB, Mommer L, Berendse F, Hoffland E (2015) Plant species richness leaves a legacy of enhanced root litter-induced decomposition in soil. Soil Biol Biochem 80:341-348. doi:10.1016/j.soilbio.2014.10.017

Cuchietti A, Marcotti E, Gurvich D, Cingolani A, Harguindeguy NP (2014) Leaf litter mixtures and neighbour effects: low-nitrogen and high-lignin species increase decomposition rate of highnitrogen and low-lignin neighbours. Appl Soil Ecol 82:44-51. doi: 10.1016/j.apsoil.2014.05.004

De Graaff M-A, Schadt CW, Rula K, Six J, Schweitzer JA, Classen AT (2011) Elevated $\mathrm{CO}_{2}$ and plant species diversity interact to slow root decomposition. Soil Biol Biochem 43:2347-2354. doi:10.1016/j. soilbio.2011.07.006

De Graaff M-A, Six J, Jastrow JD, Schadt CW, Wullschleger SD (2013) Variation in root architecture among switchgrass cultivars impacts root decomposition rates. Soil Biol Biochem 58:198-206. doi:10. 1016/j.soilbio.2012.11.015

Fan PP, Guo DL (2010) Slow decomposition of lower order roots: a key mechanism of root carbon and nutrient retention in the soil. Oecologia 163:509-515. doi:10.1007/s00442-009-1541-4

Fog K (1988) The effect of added nitrogen on the rate of decomposition of organic-matter. Biol Rev 63:433-462. doi:10.1111/j.1469-185X. 1988.tb00725.x

Galloway JN, Townsend AR, Erisman JW, Bekunda M, Cai Z, Freney JR, Martinelli LA, Seitzinger SP, Sutton MA (2008) Transformation of the nitrogen cycle: recent trends, questions, and potential solutions. Science 320:889-892. doi:10.1126/science.1136674

Gartner TB, Cardon ZG (2004) Decomposition dynamics in mixedspecies leaf litter. Oikos 104:230-246. doi:10.1111/j.0030-1299. 2004.12738.x

Goebel M, Hobbie SE, Bulaj B, Zadworny M, Archibald DD, Oleksyn J, Reich PB, Eissenstat DM (2011) Decomposition of the finest root branching orders: linking belowground dynamics to fine-root function and structure. Ecol Monogr 81:89-102. doi:10.1890/09-2390.1
Guo DL, Xia MX, Wei X, Chang WJ, Liu Y, Wang ZQ (2008) Anatomical traits associated with absorption and mycorrhizal colonization are linked to root branch order in twenty-three Chinese temperate tree species. New Phytol 180:673-683. doi:10.1111/j. 1469-8137.2008.02573.x

Harguindeguy NP, Blundo CM, Gurvich DE, Díaz S, Cuevas E (2008) More than the sum of its parts? assessing litter heterogeneity effects on the decomposition of litter mixtures through leaf chemistry. Plant Soil 303:151-159. doi:10.1007/s11104-007-9495-y

Hättenschwiler S, Gasser P (2005) Soil animals alter plant litter diversity effects on decomposition. Proc Natl Acad Sci U S A 102:15191524. doi:10.1073/pnas.0404977102

Hättenschwiler S, Jørgensen HB (2010) Carbon quality rather than stoichiometry controls litter decomposition in a tropical rain forest. $\mathrm{J}$ Ecol 98:754-763. doi:10.1111/j.1365-2745.2010.01671.x

Hättenschwiler S, Tiunov AV, Scheu S (2005) Biodiversity and litter decomposition in terrestrial ecosystems. Annu Rev Ecol Evol Syst 36:191-218. doi:10.1146/annurev.ecolsys.36.112904.151932

Hector A, Schmid B, Beierkuhnlein C, Caldeira MC, Diemer M, Dimitrakopoulos PG, Finn JA, Freitas H, Giller PS, Good J, Harris R, Högberg P, Huss-Danell K, Joshi J, Jumpponen A, Körner C, Leadley PW, Loreau M, Minns A, Mulder CPH, O’Donovan G, Otway SJ, Pereira JS, Prinz A, Read DJ, Scherer-Lorenzen M, Schulze E-D, Siamantziouras A-SD, Spehn EM, Terry AC, Troumbis AY, Woodward FI, Yachi S, Lawton JH (1999) Plant diversity and productivity experiments in European grasslands. Science 286:1123-1127. doi:10.1126/science.286.5442.1123

Hishi T (2007) Heterogeneity of individual roots within the fine root architecture: causal links between physiological and ecosystem functions. J For Res 12:126-133. doi:10.1007/s10310-006-0260-5

Kou L, Guo DL, Yang H, Gao WL, Li SG (2015a) Growth, morphological traits and mycorrhizal colonization of fine roots respond differently to nitrogen addition in a slash pine plantation in subtropical China. Plant Soil 391:207-218. doi:10.1007/s11104-015-2420-x

Kou L, Chen WW, Zhang XY, Gao WL, Li DD, Li SG (2015b) Differential responses of needle and branch order-based root decay to nitrogen addition: dominant effects of acid-unhydrolyzable residue and microbial enzymes. Plant Soil. doi:10.1007/s11104-0152517-2

Langley JA, Chapman SK, Hungate BA (2006) Ectomycorrhizal colonization slows root decomposition: the post-mortem fungal legacy. Ecol Lett 9:955-959. doi:10.1111/j.1461-0248.2006.00948.x

Li A, Guo DL, Wang ZQ, Liu HY (2010) Nitrogen and phosphorus allocation in leaves, twigs, and fine roots across 49 temperate, subtropical and tropical tree species: a hierarchical pattern. Funct Ecol 24:224-232. doi:10.1111/j.1365-2435.2009.01603.x

Lin GG, Mao R, Zhao L, Zeng DH (2013) Litter decomposition of a pine plantation is affected by species evenness and soil nitrogen availability. Plant Soil 373:649-657. doi:10.1007/s11104-013-1832-8

Liu XJ, Zhang Y, Han WX, Tang AH, Shen JL, Cui ZL, Vitousek P, Erisman JW, Goulding K, Christie P (2013) Enhanced nitrogen deposition over China. Nature 494:459-462. doi:10.1038/nature11917

McCormack ML, Eissenstat DM, Prasad AM, Smithwick EAH (2013) Regional scale patterns of fine root lifespan and turnover under current and future climate. Global Change Biol 19:1697-1708. doi: $10.1111 / \mathrm{gcb} .12163$

Megda MXV, Mariano E, Leite JM, Megda MM, Trivelin PCO (2014) Chloride ion as nitrification inhibitor and its biocidal potential in soils. Soil Biol Biochem 72:84-87. doi:10.1016/j.soilbio.2014.01. 030

Norris MD, Avis PG, Reich PB, Hobbie SE (2013) Positive feedbacks between decomposition and soil nitrogen availability along fertility gradients. Plant Soil 367:347-361. doi:10.1007/s11104-012-1449-3

Olson JS (1963) Energy storage and the balance of producers and decomposers in ecological systems. Ecology 44:322-331 
Pregitzer KS, DeForest JL, Burton AJ, Allen MF, Ruess RW, Hendrick RL (2002) Fine root architecture of nine North American trees. Ecol Monogr 72:293-309. doi:10.1890/0012-9615(2002) 072[0293:FRAONN]2.0.CO;2

Robinson CH, Kirkham JB, Littlewood R (1999) Decomposition of root mixtures from high arctic plants: a microcosm study. Soil Biol Biochem 31:1101-1108. doi:10.1016/S0038-0717(99)00028-0

Rosemond AD, Swan CM, Kominoski JS, Dye SE (2010) Non-additive effects of litter mixing are suppressed in a nutrient-enriched stream. Oikos 119:326-336. doi:10.1111/j.1600-0706.2009.17904.x

Ryan MG, Melillo JM, Ricca A (1990) A comparison of methods for determining proximate carbon fractions of forest litter. Can J For Res 20:166-171. doi:10.1139/x90-023

Shi AD, Penfold C, Marschner P (2013) Decomposition of roots and shoots of perennial grasses and annual barley - separately or in two residue mixes. Biol Fertil Soils 49:673-680. doi:10.1007/ s00374-012-0760-8

Silver WL, Miya RK (2001) Global patterns in root decomposition: comparisons of climate and litter quality effects. Oecologia 129:407419. doi:10.1007/s004420100740

Vivanco L, Austin AT (2011) Nitrogen addition stimulates forest litter decomposition and disrupts species interactions in Patagonia, Argentina. Global Change Biol 17:1963-1974. doi:10.1111/j. 1365-2486.2010.02344.x

Vos VC, van Ruijven J, Berg MP, Peeters ET, Berendse F (2013) Leaf litter quality drives litter mixing effects through complementary resource use among detritivores. Oecologia 173:269-280. doi:10. 1007/s00442-012-2588-1

Wang QK, Wang SL, Huang Y (2009) Leaf litter decomposition in the pure and mixed plantations of Cunninghamia lanceolata and Michelia macclurei in subtropical China. Biol Fertil Soils 45:371377. doi:10.1007/s00374-008-0338-7

Wang YD, Wang ZL, Wang HM, Guo CC, Bao WK (2012) Rainfall pulse primarily drives litterfall respiration and its contribution to soil respiration in a young exotic pine plantation in subtropical China. Can J For Res 42:657-666. doi:10.1139/X2012-017

Wang W, Zhang XY, Tao N, Ao D, Zeng WJ, Qian YQ, Zeng H (2014) Effects of litter types, microsite and root diameters on litter decomposition in Pinus sylvestris plantations of northern China. Plant Soil 374:677-688. doi:10.1007/s11104-013-1902-y

Wardle D, Bonner K, Nicholson K (1997) Biodiversity and plant litter: experimental evidence which does not support the view that enhanced species richness improves ecosystem function. Oikos:247258

Wen XF, Wang HM, Wang JL, Yu GR, Sun XM (2010) Ecosystem carbon exchanges of a subtropical evergreen coniferous plantation subjected to seasonal drought, 2003-2007. Biogeosciences 7:357369. doi:10.5194/bg-7-357-2010

Xia MX, Guo DL, Pregitzer KS (2010) Ephemeral root modules in Fraxinus mandshurica. New Phytol 188:1065-1074. doi:10.1111/j. 1469-8137.2010.03423.x

Xiong YM, Fan PP, Fu SL, Zeng H, Guo DL (2013) Slow decomposition and limited nitrogen release by lower order roots in eight Chinese temperate and subtropical trees. Plant Soil 363:19-31. doi:10.1007/ s11104-012-1290-8

Zahran HH (1997) Diversity, adaptation and activity of the bacterial flora in saline environments. Biol Fertil Soils 25:211-223. doi:10.1007/ s003740050306

Zhan XY, Yu GR, He NP, Fang HJ, Jia BR, Zhou M, Wang CK, Zhang JH, Zhao GD, Wang SL, Liu YF, Yan JH (2014) Nitrogen deposition and its spatial pattern in main forest ecosystems along north-south transect of eastern China. Chinese Geogr Sci 24:137-146. doi:10. 1007/s11769-013-0650-5

Zhao HM, Huang G, Ma J, Li Y, Tang LS (2014) Decomposition of aboveground and root litter for three desert herbs: mass loss and dynamics of mineral nutrients. Biol Fertil Soils 50:745-753. doi: 10.1007/s00374-013-0892-5 